УДК 338.984

\title{
CONSUMER BEHAVIOUR AND THE IDEA OF SUSTAINABLE DEVELOPMENT
}

\author{
Anna Dąbrowska \\ Institute for Market, Consumption and Business Cycles Research, \\ 87, Jerozolimskie Al., 87, Warszawa, Polska, 02-001; tel. +48 22 628-5585
}

\section{Mirosława Janoś-Kresło}

Warsaw School of Economics, 162, Niepodległości Al., Warszawa, Polska,02-554; tel. +48225646000

Sustainable development, as it is written down in the «Europe 2020» Strategy, contributes to increasing the socioeconomic and territorial cohesion. In this concept, an important role is to be played by consumers' behaviour. In their study, the authors refer to sustainable consumption as an integral element of sustainable development. A particular attention is paid to Poles' proecological behaviour in the light of authors' own survey research carried out in 2013. The research findings allowed for identification of consumers' competences treated as a stimulant of innovative behaviour and sustainable consumption.

Key words: consumer; sustainable development; proecological behaviour; strategy.

\section{Sustainable developmentas an element of the Europe 2020 Strategy}

Europe 2020 is the European Union's strategywhich refers to growth in the period of 2010-2020 and which is to help to correct drawbacks of the European model of economic growth as well as to provide conditions which will ensure that this growth will be smarter, sustainable, and socially inclusive [6]. As it is written down in the Strategy, Europe shall face the time-period of changes. As it is evaluated, the global economic crisis has wrecked effects of many years of the economic and social progress; however, it has also revealed the structural weaknesses of the European economy. More and more urgent become the problems connected with globalisation, an ever growing demand for limited resources and ageing of societies ${ }^{1}$. One can hardly object the ascertainment that Europe musttake care of its future.

More and more frequently there is paid an attention to sustainable development. Sustainable developmentis defined as the development which ensures

\footnotetext{
${ }^{1}$ Together with retiring of the population boom generation, the number of professionally active people will begin to decline in the EU starting from 2013/2014. The number of people aged $60+$ is growing today at the rate twice faster than before the year 2007, i.e. by approx. 2 million people a year - earlier, it was 1 million p.a.The smaller number of professionally active population and an increase in the number of pensioners will be an additional burden for welfare systems.
}

(C) Dąbrowska Anna, Janoś-Kresło Mirosława , 2014 
satisfaction of needs of the present generation without exerting any negative impact on the ability of future generations to meet their needs [16].

Measures for sustainable development require global actions, also because the economic systems are more and more interdependent.

Sustainable developmentcovers various areas and it means:

- building a more competitive low-emission economy which will make use of resources in a rational and economical way;

- protection of the natural environment, reduction of greenhouse gas emission, and prevention of loss of biodiversity;

- making use of the Europe's leading position to work out new, environmentfriendly technologies and production methods;

- introduction of effective, smart power engineering grids;

- making use of the grids covering the whole EUto ensure an additional market advantage to European firms (particularly to small manufacturing enterprises);

- improvement of conditions for entrepreneurship development, particularly related to SMEs.

In building sustainable development, which comprises the three main pillars: economy, society, and environment, there take part both global and local communities, partners and customers, employees and shareholders, NGOs and the government. Each of these groups has to perform definite tasks (Figure 1).

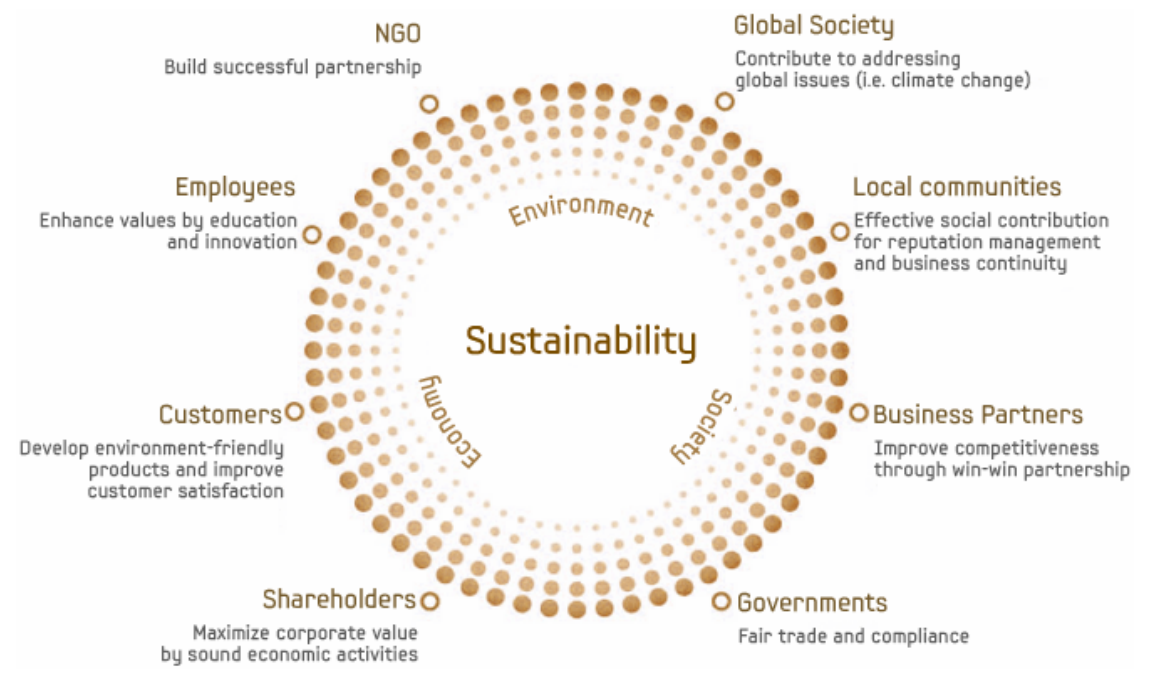

Figure 1. Sustainable developmentand its components

Sustainable development, as it is mentioned in the Strategy,means building a sustainable and competitive economy effectively exploiting resources, making for this purpose use of the Europe's leading position in the race to new processes and 
technologies, including the environment-friendly technologies, accelerating introduction of smart networks based on the ICT technologies, making use of the abilities of the networks covering the entire EU as well as reinforcing the European business' competitive advantage, especially that of the sector of production and SMEs, and assisting customers to appreciate the value of an effective use of resources. Owing to such an approach, Europe will be able to prosper in the low-emission world of limited resources, preventing at the same time degradation of the environment, loss of biodiversity, and unsustainable use of resources. These measures will also increase the economic, social and territorial cohesion.

\section{Sustainable consumptionas an integral element of sustainable development}

In the documents related to sustainable development [8], there is emphasised a great importance of consumers' behaviour, being an important factor determining the nature, scale, and directions of manufacturing processes under the conditions of market economy, particularly as regards formation of consumers' proecological attitudes. The consumers' behaviour is heavily affected by manufacturers, traders, and service providers who offer goods and services in the market as well as marketing activities and high technologies.

Pursuit to possess and consume is contemporarily prevailing in psychology of many societies, particularly the developed countries' societies as well as in an affluent group in all countries. Not without reason these societies are coined consumer societies.

The consumer society requires the bigger and bigger number of consumers and the lesser and lesser number of producers. This is so as this society is based on a continuous growth of consumer expenditure what is of an essential importance for functioning of the economic system.

Consumerism, as it is in the question, is a winner of ideological wars of the $20^{\text {th }}$ century. Consumerismis also a definite life attitude which is characterised by an excessive, despite the whole imprecision of this phrase, attachment to purchasing material goods and using a broad offer of services, which does not have its grounds in the real needs. There matter, first of all, possession, augmentation, and use of goods disregarding other values, irrespective of social, ecological, and individual costs.

The development of consumerism owes much to such phenomena as globalisation, civilizational progress, a wide choice of goods and services, free move thereof (what is guaranteed by the European Union within the framework of developed freedoms and liberalisation of the internal market for services), the possibility to purchase products on credit («buy today, pay tomorrow») and on instalments as well as development of e-commerce and e-services. 
One of the aforementioned effects of the ever growing consumerismis the problem of waste ${ }^{2}$. As the European Commission's report on waste management shows, every year the EUproduces 2.6 billion tons of waste, of which more than 90 million tonsis considered as dangerous. It is recommended to establish a special agency at the level of the European Union whose task would be to resolve basic problems connected with implementation and enforcement of the European waste-related regulations. In the recent years, in result of an increase of amounts of waste produced and relocated in the enlarged EU, the problem has become very crucial.

In theEuropean Union, as Eurostat has announced, there was produced in 2011 amount of 503 kgof municipal solid waste per capita, of which there were managed $486 \mathrm{~kg}$ : tips accumulated $37 \%$ (in 2001, it was $56 \%$ ), incinerators received $23 \%$ (in $2001-17 \%$ ), forrecycling - $25 \%$ (in $2001-17 \%$ ), andcomposting plants received $15 \%$ (in $2001-10 \%$ ). The biggest amounts of waste are produced by Denmark - 718 $\mathrm{kg}$ per capita. Luxembourg, Cyprus, and Ireland produce 600-700 kg per capita, whereasGermany, the Netherlands, Malta, Austria, Italy, Spain, France, the United Kingdom, and Finland - 500-600 kg per capita. In Greece, Portugal, Belgium, Sweden, Lithuania, and Slovenia, this index accounts for 400-500 kg per capita. Poland, together with Hungary, Romania, Bulgaria, Latvia, Slovakia, the Czech Republic, and Estoniais in the group of countries producing less than $400 \mathrm{~kg}$ of waste per capita [12].

A further issue is food wasting. Every year, in the EU households, supermarkets, and restaurants as well as within the food chain, there is wasted even up to $50 \%$ of food. On the other hand, 79 million EUcitizens live below the poverty threshold and 16 million receive food aid from charity institutions. At present, in the EU-27, there are wasted annually $89 \mathrm{mn}$ tonsof food (i.e. $179 \mathrm{~kg}$ per capita). Unless there are taken relevant measures, it is estimated that in the year 2020 this amount will grow to 126 million tons (i.e. by $40 \%$ ) [13].

It is worth to quote here the words uttered by Z. Bauman: «From among the skills necessary for practising the art of living under the conditions of fluent modernity, of greater importance is the ability to get rid of things than the skill to achieve them» $[1$, p. 6].

As J. Szczepański writes, we can look at the human kind development «as on the development of individual's traits enabling their adaptation to the collective life and participation therein, but also as an ability to perform the group tasks, inconsistent

\footnotetext{
${ }^{2} \mathrm{~A}$ very important regulation on the municipal waste management is the Directive No. 94/62/ECon packaging and packaging waste. It imposes the obligation to set up a system and to achieve definite percentage levels of waste recovery and recycling. Recovery is understood here as reuse, through recycling, of waste and incineration with energy recovery or composting, or biodegradation. The Member States have to recover from 50 to $65 \%$ of the mass of waste from packaging, and the reuse through waste recycling $-25-45 \%$, and at least $15 \%$ of every material.
} 
Anna Dąbrowska, Mirosława Janoś-Kresło

ISSN 2078-4333. Вісник Львівського університету. Серія міжнародні відносини. 2014. Випуск 36. Частина 1

with their personal interests, i.e. the ability to act in an altruistic manner, disregarding what the ultimate motivation thereof is. Thus, the human being - a participant of the social life - is a beinginternalising society's values, behaving in accordance with those values imperatives, and acting towards retention and development thereof» $[15$, p. 53].

The ongoing evolution of the consumer towards the prosumer, named a «forefront of consumers of the $21^{\text {st }}$ century», who individualise their consumption, do not want to yield to the culture of consumerism, forces us to look in a different way at the decision-making process, forms of communication between the market participants, the manner of meeting their needs. There is also growing the awareness of various aspects of the human quality of life and health as well as its relationships with consumption what makes us realise that consumption is not a self-existent objective.

There is perceived a ware-out by consumerism, an excessive consumption connected with satisfaction of adjacent needs, and perception of consequences of such behaviour attracts attention, at least of a part of consumers, to the idea of sustainable consumption.

Sustainable consumptionis a counterbalance for consumerism. The International Institute for Environment and Development describes sustainable consumption as a strategy for formation of demand aimed at exploitation of natural resources and business services for the purpose of meeting needs and raising the quality of life of all people, with a simultaneous reproduction of the natural capital for future generations [11].

Sustainable consumptionis an optimal, conscious, and responsible use of the accessible natural resources, goods and services at the level of individuals, households, local communities, business circles, local governments, national governments, and international structures, in compliance with the principles of sustainable development. It is aimed at meeting needs and raising the quality of life in local and global terms, with observance of human rights and employment rights, taking into account an opportunity to meet needs of other people, including those of future generations, and with maintenance and reproduction of the natural capital for them. Sustainable consumptionattitude takes into consideration reduction of wastage, production of waste and pollutants as well as choice of goods and services which ultimately meet the definite ethical, social and environmental criteria.

As D. Kiełczewski comments, sustainable consumptionis such a structure of the system of consumption where the shape of individual sets as well as relationships and interdependences between them enable achievement of the goals of sustainable development. In effect, consumption of the contemporary generation does not limit the opportunities for consumption in case of the future generations pursuant to the postulate contained in the BrundtlandCommission definition («Sustainable developmentof Earth is development that meets the essential needs of all people as well as maintains, protects and restores health and integrity of the Earth ecosystemwithout compromising the ability of future generations to meet their own 
needs and not exceeding the long-term limits of the Earth ecosystem's capacity») [10, p. 62].

Implementation of the concept of sustainable consumptionrequires the conscious consumer, i.e. such, which, while buying goods and services, behaves prudently and ethically, i.e. who realises the consequences of their purchasing decisions, who chooses products of the enterprises guided not only by the economic principles but also ecological, social, and ethical ones [4].

Among the new phenomena affecting consumers' behaviour one may single out collaborative consumption [5]. This is a movement of conscious and sustainable consumption which is in opposition to consumerism, the cult of possession. R. Botsman and Rogers R. define this notion as a socioeconomic idea that has an opportunity to revolutionise the way in which we consume [3]. The idea of «community consumption» is the ability to share, the propensity to borrow, lend, hire. A great role is played here by technologiesandcommunity portals but also confidence in other people. Consumers exchange goods (e.g.clothes), provide accommodation (couchsurfing), share skills.

A reaction to tire by the incessant pursuit of goods is undertaken measures of the educational nature and organised anti-consumption movements, e.g. Slow Movement or the Buy Nothing Day.

The European Union's means assigned for sustainable consumptionandproduction are focused on the four main aims: better products, more rational consumption, more effective and ecological production, and support given to global measures.

The conditions of permanence of sustainable consumptionin the subject arrangement according to D. Kiełczewskiare: equilibrium between consumption and savings, assurance of consumers' stable material situation,differentiation of consumers' incomes facilitating growth of effectiveness of the economy's sectors whose development is conducive to achievement of the goals of sustainable development,minimisation of the number of consumers realising consumption without work performance,popularisation of ecological awareness,recognition in consumers' budgets of prices for environmental goods and services [9].

In the National Development Strategy 2020, there is emphasised that efficacy of measures in the area of rational natural resource management is determined by raising society's awareness and requires promotion of ecological behaviour of Poles by way of implementation of properly adopted and directed educational and information measures.

Sustainable consumptionis an element of sustainable developmentand is connected with definite behaviour. More and more often the idea of homo oeconomicusis opposed to the idea of homo sustinens. As D. Kiełczewskinotes, the idea of homo oeconomicus is more and more frequently criticised and, after G. Kirchgassner, refers to the basic assumptions of behaviour pertinent to homo oeconomicus, namely:

- peoplemake decisions independently of one another; therefore, the individual isthe basic entity of an economic analysis; 
Anna Dąbrowska, Mirosława Janoś-Kresło

ISSN 2078-4333. Вісник Львівського університету. Серія міжнародні відносини. 2014. Випуск 36. Частина 1

- individuals behave reasonably in the economic sense;

- the entire behaviour of individuals is oriented on augmentation of one's benefits $[9$, p. 217].

The concept of homo sustinens, as, inter alia, B. Fiedor [7] and D. Kiełczewski emphasise, isstrictly connected with the idea of sustainable development. It's about the shift from the society excessively exploiting natural resources to the society conserving those resources. According to B. Fiedor, there will go in vain even the best-thought-out and cohesive actions carried out by the state and international activity in the sphere of legal and administrative as well as economic and market regulation in environment protection and its resources management if there do not take place fundamental changes in awareness and homo oeconomicusdoes not become at least partially homo sustinens.

\section{Poles' proecological behaviour in the light of authors' own research findings}

Consumers' behaviour is a body of measures connected with achievement and use of goods and services as well as disposal thereof, together with the decisions preceding and determining those measures $[2, \mathrm{p} .4]$. Consumer's behaviour may be explained by the description of internal reactions of the consumer to the stimuli affecting them.

In order to identify consumers' competences, treating them as stimulantsof innovative behaviour and sustainable consumption, there were carried out in 2013 quantitative surveys on the 1000-individuals sample of adult Poles and qualitative surveys $(\mathrm{FGI})^{3}$.

In the qualitative surveys, the respondents were asked to define the notion of sustainable consumption. This term was associated to consumers with:

- Planning: planning one's purchases, not buying casual things, selecting with sense, being guided by prudence, choosing good-quality products and the ones already learned, saving - high quality leads to savings, despite higher price; good management of one's budget as well as not buying unnecessarily, moderation: «I buy the quantity I need or what is necessary; I prepare shopping lists, I do not waste».

- Awareness, know-how: good market orientation (where/what/how), knowledge of the commodity, non-compliance to advertisements or fashions, balance between consumption (buying) and being aware of what is being bought, combination of ecology and economy but also awareness of the choice - knowledge of where the product comes from and what its composition is.

- Ecology, care of the nature: non-wastage - use «till the end and only then buying the next thing», recycling - reuse of some products, ecology - guarantee of

\footnotetext{
${ }^{3}$ The surveys were implemented to the project: Kompetencje konsumentyw jako stymulanta innowacyjnych zachowan i zrywnoważonej konsumpcji, financed on the means of the National Science Centre. The project manager is Dr hab. Anna Dąbrowska.
} 
product quality, naturalness, care of the natural environment- important are markings (especially the ecological ones, as well as those pertinent to testing on animals cosmetics, chemicals); lack thereof may discourage from a given producer or firm, making use of other people's abilities - exchange of knowledge, skills or products as well as non-damaging oneself or the world.

- Loyalty, ethics: knowledge of the production process and product's composition, supporting excluded manufacturers, e.g. cooperatives employing the disabled, unemployed, producers rights protection (protection of children from China), not cheating oneself and the family as well as taking and returning (clothes/books).

Inturn, in the quantitative surveys, sustainable consumptionwas associated by the respondents, first of all, with well-thought-out purchases $(25 \%)$ and buying the products that are necessary $(24 \%)$ as well as consumption with moderation, adequately to financial capabilities $(21 \%)$. It must be emphasised that about $1 / 3$ of Polescould not define the behaviour underlying the term «sustainable consumption» (significantly more often admit their lack of knowledge individuals with primary/vocational education - $49 \%$, negatively assessing their knowledge of sustainable consumption - $40 \%$ ) - Figure 2 .

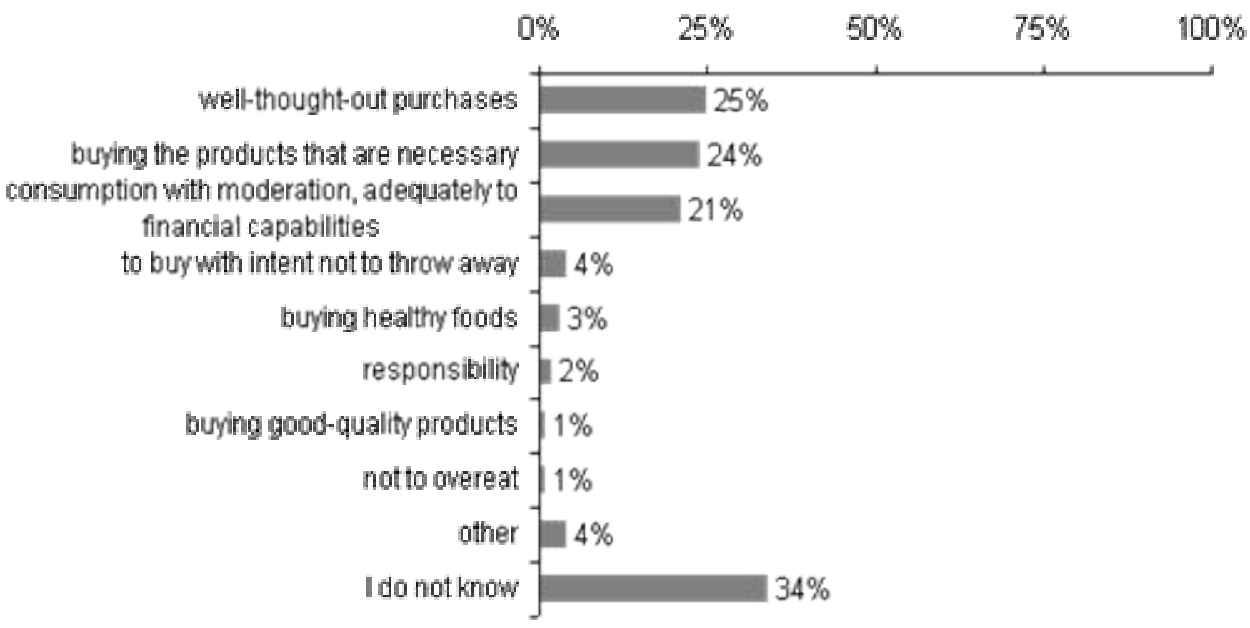

Figure 2. Perception of sustainable consumption

Source: Own research surveys, 2013.

As the main barriers for application of the rules of sustainable consumptionthere are considered:finances (products are too expensive); lack of accessto knowledge (stand-by, chargers in the socket - instead of facts, everyone only knows rumours); lackof knowledge of the products; there are no authorities - low social awareness of consumer organisations;lackof independent, reliable products evaluations; lackof time, 
Anna Dąbrowska, Mirosława Janoś-Kresło

ISSN 2078-4333. Вісник Львівського університету. Серія міжнародні відносини. 2014. Випуск 36. Частина 143

rate of life; lackof reliable guarantees of products reliability; laziness, ease; lackof accessto an adequate background, e.g. recycling bins or containers; lackof willingness, interest, ignorance, indifference; lackof thinking of the future; greed and willingness to save: «Sometimes we buy a cheaper product and, as it comes out, unfortunately, the purchase isineffective, so we collect money for that more expensive»; lack of moderation - «sometimes we buy too much»; lack of access to adequate products; upto-datedness, trends in fashion; excess of products, glut in the market (you never know which are good); lack of ability to do something by oneself; policy of large firms, corporations, and producers (e.g. «in Poland, for a long time, there was banned stevia, a natural sweetener, which was put on the list of illegal substances»).

\section{Resumption}

Sustainable development is currently a dominating concept of the socio-economic development which is widely highlighted in its documents by the European Union. In the concept of sustainable development, a great importance is attributed to consumers' behaviour, particularly proecological behaviour.

Speaking of the contemporary consumption, on the one hand, there is paid attention to the phenomenon of consumerism and its effects in the form of, inter alia, permanently increasing volume of waste or food wastage. On the other hand, as a counterbalance for consumerism there is treated sustainable consumption, paying attention to the new phenomena as, for example, collaborative consumptionor anticonsumption movements. As the surveys show, Poles differently associate the term «sustainable consumption», not all were able to define behaviours associated with this term, either.

Change of consumers' behaviour to that compliant with the concept of sustainable development and sustainable consumption requires educational activities. Those activities should be addressed not only to consumers but also to producers and traders. Achievement of progress in implementation of the idea of sustainable development and consumption requires undertaking measures by all as we all are responsible for the environment we live in.

\section{REFERENCES}

1. Bauman Z. Płynne życie / Z. Bauman. - Warsaw : Wydawnictwo Literackie, 2007.

2. Blackwell R. D. Consumer Behavior / R. D. Blackwell, J. F. Engel, P. W. Miniard. Chicago : The Dryden Press, 1995.

3. Botsman R. What's Mine Is Yours: The Rise of Collaborative Consumption / R. Botsman, R. Rogers. - 2010.

4. Dabrowska A. Edukacja konsumenta - potrzeba czy wyzwanie XXI wieku / A. Dąbrowska // Marketing i Rynek. - 2001. - № 12.

5. Dabrowska A. Konsument na rynku usług w Polsce, Instytut Badań Rynku, Konsumpcji i Koniunktur / A. Dąbrowska // Warsaw, 2013. 
6. Europe 2020. A strategy for smart, sustainable and inclusive growth. Communication from the Commission [Electronic resource]. -2010 . Available at : http://eurlex.europa.eu/LexUriServ/LexUriServ.do?uri= COM:2010:2020:FIN:EN:PDF.

7. Fiedor B., Homo oeconomicus kontra homo sustinens [Electronic resource] Available at : http://kropla.eko.org.pl/newkropla/?pismo $=33 \&$ kolejny $=5$.

8. Inter alia Polska 2025 - długookresowa strategia trwałego i zrywnoważonego rozwoju // Government Centre for Strategic Studies in cooperation with the Ministry of Economy, adopted by the Parliament of the Republic of Poland on 2 March 1999.

9. Kietczewski D. Homo oeconomicus i homo sustinens jako wyzwania ekonomii zrywnoważonego rozwoju / D. Kiełczewski // Teoretyczne aspekty ekonomii zrywnoważonego rozwoju. - Białystok : Wydawnictwo Wyższej Szkoły Ekonomicznej w Białymstoku, 2011.

10. Kielczewski D. Konsumpcja a perspektywy zrywnoważonego rozwoju / D. Kiełczewski. - Białystok : Uniwersytet w Białymstoku, 2008.

11. Kozakiewicz $M$. Zrywnoważona konsumpcja - trendy kształtujące naszą przyszłość [Electronic resource] Available at htpp://www.opoka.org.pl/biblioteka/X/XB/konsumeryzm.html.

12. More than $500 \mathrm{~kg}$ of municipal waste per capita in the EU [Electronic resource] Available at: http://www.administrator24.info/artykul /id4618,ponad-500-kg-odpadowkomunalnych-na-osobe-w-ue.

13. Prevention and reduction of food waste [Electronic resource] - Available at : http://www.eesc.europa.eu/?i=portal.en.nat-opinions. 25955.

14. Strategia Rozwoju Kraju 2020 - Aktywne społeczeństwo, konkurencyjna gospodarka, sprawne państwo, Ministerstwo Rozwoju Regionalnego // Warsaw, 2013.

15. Szczepański J. Konsumpcja a rozwyj człowieka. Wstęp do wstęp do antropologicznej teorii konsumpcji / J. Szczepański. - 1981. - 349 s.

16. UN Documents: Report of the World Commission on Environment and Development: Our Common Future [Electronic resource] - Available at : http://www.un-docements.nt/wcedocf.htm.

Стаття надійшла до редколегії 01.11.2014. Прийнята до друку 01.12.2014. 
Anna Dąbrowska, Mirosława Janoś-Kresło

ISSN 2078-4333. Вісник Львівського університету. Серія міжнародні відносини. 2014. Випуск 36. Частина 1

ПОВЕДІНКА СПОЖИВАЧІВ ТА ІДЕЯ СТАЛОГО РОЗВИТКУ

\author{
Анна Добровська \\ Інститут ринку, спожсивання і дослідження бізнес ичилів, \\ Алея Срусалимська, 87, м. Варшава, Республіка Польща, 02-001; \\ тел. +4822 628-5585
}

Мирослава Янош-Кресло

Варшавська школа економіки, Алея Незалежності, 162, м. Варшава, Республіка Польща, 02-55; тел. +48225646000

Сталий розвиток, як це записано в Стратегії «Європа 2020», сприяє підвищенню соціальноекономічної та територіальної згуртованості. У цій концепції важливу роль відіграє поведінка споживачів. У своєму дослідженні автори посилаються на концепцію сталого споживання як невід'ємного елементу сталого розвитку. Особливу увагу приділено екологічній поведінці поляків у світлі власних досліджень та опитувань авторів, проведених 2013 року. Результати дослідження дали змогу ідентифікувати споживачів як стимулятор інноваційної поведінки та сталого споживання.

Ключові слова: споживач; сталий розвиток; проекологічна поведінка; стратегія.

\title{
ПОВЕДЕНИЕ ПОТРЕБИТЕЛЕЙ И ИДЕЯ УСТОЙЧИВОГО РАЗВИТИЯ
}

\author{
Анна Добровская \\ Институт рынка, потребления и исследования бизнес-ииклов, \\ Алея Ерусалимская, 87, г. Варшава, Республика Польша,02-001; \\ тел. +4822 628-5585 \\ Мирослава Янош-Кресло \\ Варшавская школа экономики, \\ Аллея Независимости, 162, г. Варшава,Республика Польша, 02-554; \\ тел. +48225646000
}

\begin{abstract}
Устойчивое развитие, как это записано в Стратегии «Европа 2020», способствует повышению социально-экономической и территориальной сплоченности. В этой концепции важную роль играет поведение потребителей. В своем исследовании авторы ссылаются на концепцию устойчивого потребления как неотъемлемого элемента устойчивого развития. Особое внимание уделено экологическому поведению поляков в свете собственных исследований и опросов авторов, проведенных в 2013 году. Результаты исследования позволили идентифицировать потребителей как стимулятор инновационного поведения и устойчивого потребления.
\end{abstract}

Ключевые слова: потребитель; устойчивое развитие; проэкологическое поведение; стратегия. 